\title{
Potensi Bakteri Enterobacter cloacae sebagai Biodegradator Herbisida Glifosat pada Media Tanah
}

\section{Potency of Enterobacter cloacae Bacteria as Glyphosate Herbicide in Soil Media}

\author{
Lutfi Tri Andriani \\ Balai Besar Pelatihan Pertanian (BBPP) Ketindan, Jl. Ketindan, No. 1 Lawang Malang 65214 \\ lutfi.tri.andriani@gmail.com
}

INFO ARTIKEL ABSTRACT / ABSTRAK

Sejarah Artikel

Dikirim:

1 Juli 2021

Diterima:

30 Juli 2021

Terbit:

31 Juli 2021
Bakteri pemacu pertumbuhan tanaman telah dikenal luas di kalangan masyarakat. Bakteri tersebut memiliki sebagai biostimulan, bioprotektan dan biofertilizer. Beberapa jenis dari bakteri pemacu pertumbuhan tanaman, memiliki kemampuan untuk tumbuh pada lingkungan ekstrim. Penggunaan herbisida kimia sangat tinggi. Penguraiannya dapat terjadi dengan cara penjerapan oleh partikel tanah, penguraian juga dapat dibantu oleh cahaya, air, dan mikroorganisme. Oleh karena itu, perlu pengujian tentang potensi bakteri pemacu pertumbuhan tanaman dalam mendegradasi herbisida kimia. Pangkajian ini bertujuan untuk mengetahui kemampuan bakteri Enterobacter cloacae dalam mendegradasi glifosat. Pengujian dilakukan pada sampel tanah yang ditambahkan glifosat dan isolat bakteri Enterobacter cloacaae yang merupakan anggota dari bakteri pemacu pertumbuhan tanaman yang dibandingkan dengan kontrol Selanjutnya, residu glifosat setelah perlakuan, diukur dengan menggunakan High Performance Liquid Chromatography (HPLC). Hasil menunjukkan bahwa bakteri Enterobacter cloacae dapat mendegradasi glifosat. Hasil pengujian konsentrasi residu glifosat pada medium tanah yang telah diberikan perlakuan dengan penambahan bakteri Enterobacter cloacae dan Tanpa penambahan bakteri Enterobacter cloacae, yaitu pada perlakuan tanpa penambahan bakteri Enterobacter cloacae, kadar glyfosat yang diperoleh sebanyak 51, 4 ppm dan kadar Aminomethylphosponate (AMPA) sebanyak 4,66 ppm sampel. Sedangkan pada medium tanah dengan penambahan bakteri Enterobacter cloacae, yaitu pada kadar glyfosat sebanyak 0 ppm dan kadar Aminomethylphosponate (AMPA) sebanyak 12,8 ppm sampel.

Plant growth-promoting bacteria have been widely known among the public. These bacteria have as biostimulants, bioprotectants and biofertilizers. Some types of plant growth-promoting bacteria, have the ability to grow in extreme environments. The use of chemical herbicides is very high. Decomposition can occur by adsorption by soil particles, decomposition can also be assisted by light, water, and microorganisms. Therefore, it is necessary to examine the potential of plant growth-promoting bacteria in degrading chemical herbicides. This study aims to determine the ability of Enterobacter cloacae in degrading glyphosate. The test was carried out on soil samples added with glyphosate and isolates of Enterobacter cloacaae which is a member of plant growth promoting bacteria compared to controls. Furthermore, glyphosate residues after treatment were measured using High Performance Liquid Chromatography (HPLC). The results showed that Enterobacter cloacae bacteria could degrade glyphosate. The results of testing the concentration of glyphosate residues in the soil medium that have been treated with the addition of Enterobacter cloacae bacteria and without the addition of Enterobacter cloacae bacteria, namely in the treatment without the addition of Enterobacter cloacae bacteria, the levels of glyphosate obtained are $51.4 \mathrm{ppm}$ and levels of Aminomethylphosponate (AMPA) are $4.66 \mathrm{ppm}$ sample. While the soil medium with the addition of Enterobacter cloacae bacteria, namely the glyphosate content of $0 \mathrm{ppm}$ and the level of Aminomethylphosponate (AMPA) as much as $12.8 \mathrm{ppm}$ sample

This is an open access article under the CC-BY license. 


\section{Pendahuluan}

Keamanan pangan penting dilakukan tidak hanya sebagai upaya mendukung aspek kesehatan masyarakat namun juga mendukung peningkatan kualitas dan ketahanan suatu bangsa. Sejalan dengan tema besar Hari Keamanan Pangan Sedunia yaitu "Keamanan Pangan, Tanggung Jawab Bersama", maka semua elemen masyarakat perlu menyadari tanggung jawab terhadap keamanan pangan. Lukito (2020) menyampaikan bahwa semua orang memiliki peran dan tanggung jawab memastikan keamanan sepanjang rantai pangan dari hulu ke hilir, dari budidaya sampai meja makan (from farm to table). Terdapat lima seruan aksi peringatan Hari Keamanan Pangan Sedunia, yaitu (1) Ensure it's safe, dimana Pemerintah harus memastikan pangan aman dan bergizi untuk semua; (2) Grow it safe, yaitu penerapan good practices oleh produsen produk pertanian dan pangan; (3) Keep it safe, bahwa pelaku usaha harus memastikan produk pangan tetap aman; (4) Eat it safe, bahwa semua konsumen berhak atas pangan aman, sehat, dan bergizi; dan (5) Team up for safety, yaitu keamanan pangan adalah tanggung jawab bersama.Untuk dapat menjaga keamanan pangan dari hulu, maka tahapan pelaksanaan budidaya tanaman diupayakan minimal penggunaan bahan kimia. Namun, realita di lapangan, penggunaan pupuk dan pestisida kimia untuk pengendali hama dan penyakit tumbuhan cukup berlebihan, kurang sesuai dengan kaidah yang berlaku dan kurang bijaksana, hingga menyebabkan residu pada tanah dan produk pertanian. Glifosat, merupakan bahan kimia pengendali gulma (herbisida). Penggunaan herbisida ini sangat tinggi, bersifat sistemik sehingga lebih disukai oleh pengguna. Glifosat menyebabkan dampak negatif di lingkungan dan manusia, antara lain sulit terurai, menyebabkan biomagnifikasi, dapat menimbulkan gangguan endokrin dalam sel plasenta manusia pada dosis di bawah dosis pertanian, dalam 24 jam, dan pada lini sel manusia (Richard et al., 2005; Gasnier et al., 2009 dalam TWN, 2013). Residu herbisida glifosat terdeteksi di areal pertanaman dan tertranslokasi ke dalam produkhasil panen merupakan residu yang terkonsumsi oleh konsumen, dan terakumulasi dalam tanah, serta potensial terserap akan tanaman berikutnya. Residu herbisida inilah yang dalam jangka panjang akan menyebabkan gangguan kesehatan yaitu pada syaraf maupun metabolisme enzim. Residu pestisida terbawa nelalui rantai makanan akan terakumulasi dalam jaringan tubuh yang mengandung lemak. Akumulasi residu pestisida ini pada manusia dapat merusak fungsi hati, ginjal, sistem syaraf, menurunkan kekebalan tubuh, menimbulkan cacat bawaan, alergi dan kanker (Munarso, 2016 dalam Fauriah et al., 2017)).

Penguraian pestisida kimia memerlukan waktu yang cukup lama. Penguraian dapat melalui proses fotodegradasi, pencucian oleh air hujan dan degradasi yang dibantu oleh mikroorganisme. Bakteri pemacu pertumbuhan tanaman, memiliki kelebihan biostimulan, bioprotektan dan biofertilizer. Bakteri pemacu pertumbuhan terdapat di perakaran (rhizosfer) dan di dalam tanaman (endofit). Bakteri yang tergolong pemacu pertumbuhan perakaran (Plant growth promoting rhizobacteria/ PGPR) antara lain golongan Azospirrilium, Azotobacter, Bacillus, Enterobacter, Gordonia, Klebsiella, Paenibacillus, Pseudomonas, Serratia, dan lainnya. Keberadaannya di sekitar perakaran memungkinkan terpapar oleh herbisida. Menurut Zhuang et al. (2007) PGPR memiliki kemampuan mendegradasi kontaminan organik dan anorganik di dalam tanah. Stepniewska et al. (2013) menyatakan bahwa mikroorganisme endofit berpotensi dalam membantu biodegradasi kontaminan/ polutan seperti pestisida, polychlorobiphenil dan lainnya. Pengendalian gulma saat ini masih sangat tergantung pada herbisida kimia sintetik. Apabila digunakan secara terus menerus dan berlebihan, herbisida kimia sintetik akan berdampak negatif bagi kesehatan manusia dan lingkungan, sehingga perlu alternatif cara meningkatkan degradasi herbisida kimia. Salah satunya dengan menggunakan bakteri pemacu pertumbuhan baik yang di perakaran maupun yang endofit. Oleh karena itu, tujuan penelitian ini menganalisis potensinya dalam mendegradasi herbisida.

\section{Metodologi}

\subsection{Tempat Penelitian}

Penelitian ini dilaksanakan di laboratorium bakteriologi, Fakultas Pertanian, Universitas Brawijaya, Malang, Indonesia.

\subsection{Tahapan Penelitian}

\subsubsection{Kultur Bakteri}

Isolat bakteri pemacu pertumbuhan yang digunakan adalah Bakteri Enterobacter cloacae. Pemurnian bakteri dilakukan dengan streak koloni tunggal pada media NA dan kemudian diperbanyak dengan menggoreskan koloni tunggal pada media NA yang baru.

\subsubsection{Uji Kemampuan Bakteri dalam Mendegradasi Herbisida Glifosfat pada Medium Tanah}

Pengujian dilaksanakan dengan menggunakan tanah bagian permukaan (kedalaman 0-15 cm). Tanah disterilkan dengan autoklaf sebanyak tiga kali pada suhu $121^{\circ} \mathrm{C}$ selama 25 menit. Herbisida glifosat dicampur dengan $1 \mathrm{~kg}$ tanah dengan cara menambahkan $250 \mathrm{ml}$ aquades steril yang telah ditambahkan herbisida glifosat sebanyak $125 \mu \mathrm{l}$ dan suspensi bakteri sebanyak $1 \mathrm{ml}$ pada perlakuan bakteri dan tidak dilakukan penambahan 
bakteri pada perlakuan tanpa bakteri. Inkubasi dilakukan pada suhu ruang kondisi gelap. Residu herbisida diukur 7 hari setelah inkubasi dengan menggunakan alat High Performance Liquid Chromatography. Ekstraksi untuk sampel tanah dilakukan dengan mengambil tanah sebanyak $25 \mathrm{~g}$, setiap sampel dimasukkan ke dalam erlenmeyer dan ditambahkan aseton sebanyak $100 \mathrm{ml}$, selanjutnya dishaker selama 30 menit. Ekstrak tanah kemudian disaring dan dimasukkan ke labu rotary evaporator, kemudian diuapkan hingga tersisa $\pm 1 \mathrm{ml}$ yang merupakan residu herbisida. Dinding labu dibilas dengan $10 \mathrm{ml}$ asetonitrile $85 \%$

\subsection{Parameter Pengamatan}

Persentase degradasi pada medium tanah dihitung dengan rumus:

$$
\% \text { degradasi }=\frac{a-b}{a} \times 100
$$

Dimana :

$\mathrm{a}=$ kadar glifosat perlakuan glifosat tanpa bakteri

$\mathrm{b}=$ kadar glifosat perlakuan glifosat dengan penambahan bakteri

\section{Hasil dan Pembahasan}

Glifosat adalah herbisida yang mempunyai spektrus pengendalian luas bersifat nonselektif. glifosat sangat efektif mengendalikan gulma rumput dan daun lebar yang mempunyai perakaran dalam dan diaplikasikan sebagai herbisida pascatumbuh. Glifosat merupakan herbisida yang bersifat sistemik dan tidak selektif pascatumbuh. Glifosat dapat berpengaruh pada pigmen hingga terjadi klorotik,pertumbuhan terhenti dan pertumbuhan dapat mati (Moenandir, 2010). Penguraian pestisida kimia memerlukan waktu yang cukup lama. Penguraian dapat melalui proses fotodegradasi, pencucian oleh air hujan dan degradasi yang dibantu oleh mikroorganisme. Stenersen (2004) menyatakan bahwa mikroorganisme jenis Arthrobacter atau Pseudomonas memiliki kemampuan mendegradasi herbisida. Selain itu, bakteri yang termasuk Pseudomonas, Bacillus, Klebsiella, Pandoraea, Phanerochaeta chrysosporium, Mycobacterium dilaporkan memiliki kemampuan mendegradasi pestisida (Odukkathil, 2013). Khrishna dan Philip (2011) menyatakan bahwa bakteri jenis Pseudomonas aeruginosa dapat mendegradasi methyl parathion dan Bacillus sp mendegradasi Lindane. Penelitian tersebut mengungkapkan bahwa bakteri memiliki kemampuan membantu degradasi berbagai jenis pestisida. Residu glifosat, diukur dengan menggunakan High Performance Liquid Chromatography (HPLC) dengan Triple Quadrupole Tandem Mass Spectrometry detector (LC-MS/MS).

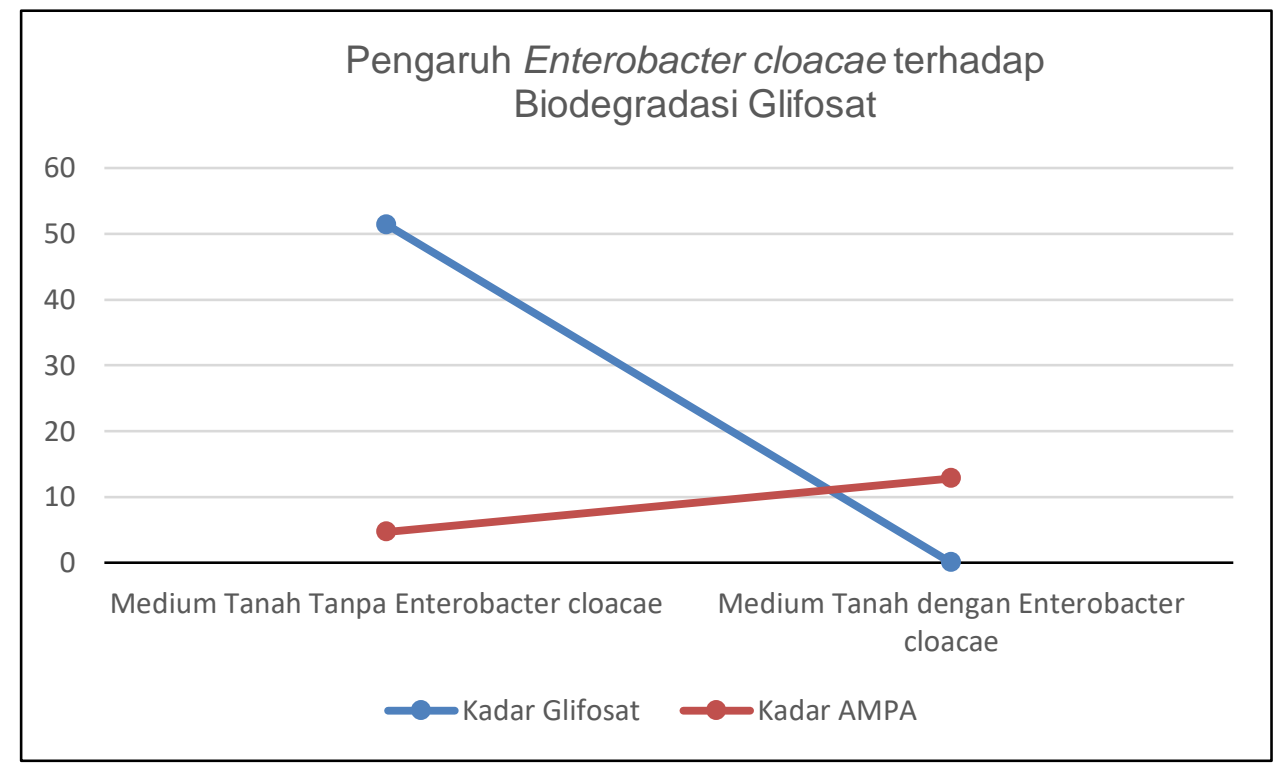

Gambar 1. Pengaruh Bnterbacter cloacae terhadap biodegradasi glifosfat

Hasil pengujian konsentrasi residu glifosat pada medium tanah yang telah diberikan perlakuan dengan penambahan bakteri Enterobacter cloacae dan Tanpa penambahan bakteri Enterobacter cloacae, yaitu pada perlakuan tanpa penambahan bakteri Enterobacter cloacae, kadar glyfosat yang diperoleh sebanyak 51, 4 ppm dan kadar Aminomethylphosponate (AMPA) sebanyak 4,66 ppm sampel. Sedangkan pada medium tanah dengan penambahan bakteri Enterobacter cloacae, yaitu pada kadar glyfosat sebanyak 0 ppm dan kadar Aminomethylphosponate (AMPA) sebanyak 12,8 ppm sampel. Sehingga, dapat disampaikan bahwa presentase 
biodegradasi herbisida glifosat dengan menambahkan bakteri Enterobacter cloacae sekitar 100\%. Hal ini menunjukkan bahwa bakteri Enterobacter cloacae memiliki potensi kemampuan untuk mendegradasi bahan aktif glifosat. Mekanisme biodegradasi herbisida glifosat pada medium tanah, diduga melalui jalur degradasi aminomethylphosponate/ AMPA (Gambar 2). Hal ini dibuktikan dengan pengujian pada perlakuan Kontrol dan Bakteri Enterobacter cloacae dimana pada perlakuan kontrol, kadar AMPA rendah yaitu 4,66 ppm berbeda dengan perlakuan bakteri E1 yaitu kadar AMPA meningkat menjadi 12,8 ppm.

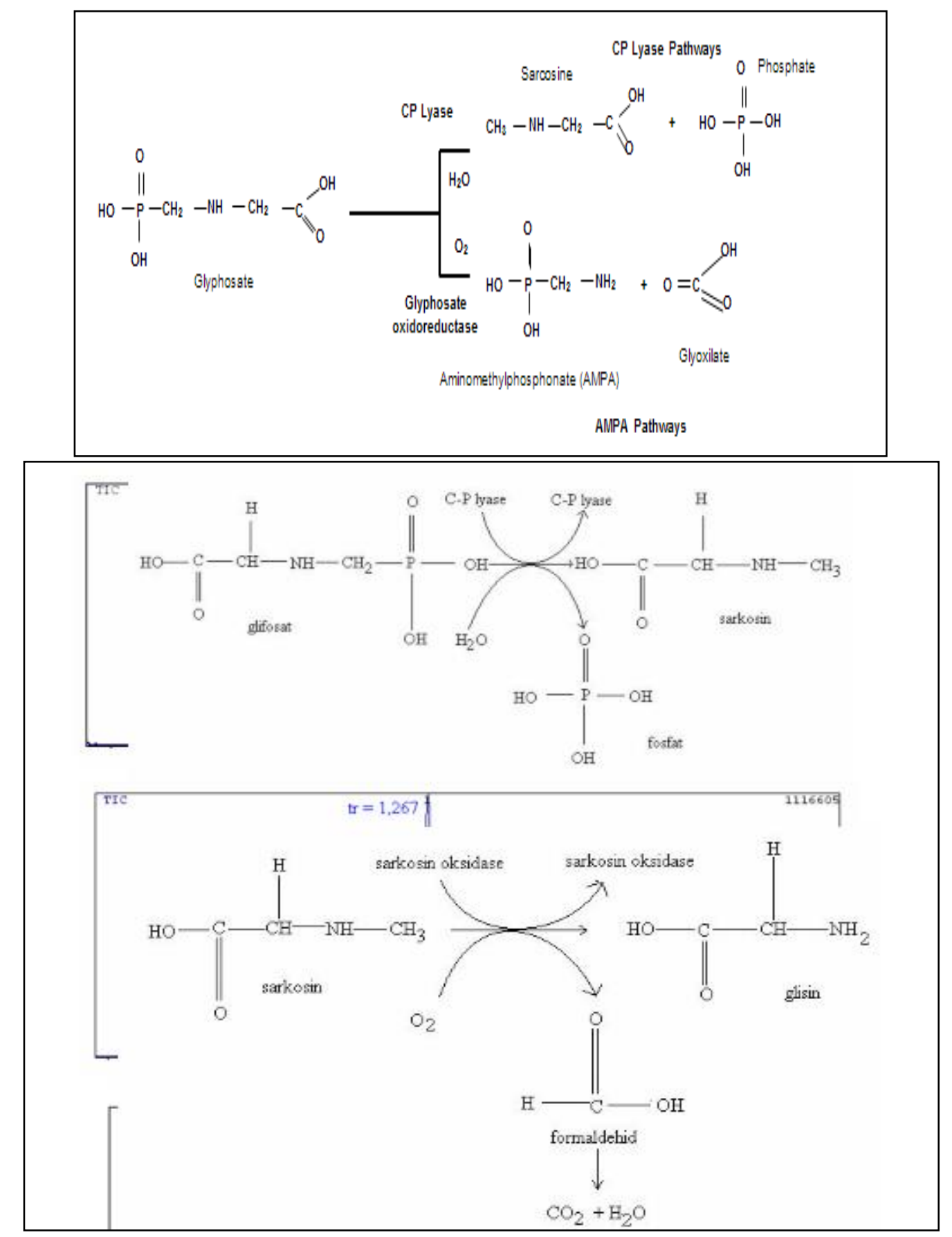

Gambar 2. Jalur degradasi glifosfat

Sumber: Pollegioni et al., 2011

Pada tanah dengan jumlah air yang terbatas, glifosat terdegradasi dengan bantuan oksigen dan terpecah menjadi AMPA dan Glyoxilate. Degradasi glifosat (detoksifikasi) dapat menjadi cara untuk meminimalkan resistensi glifosat. Mikroorganisme tanah dapat memetabolisme glifosat dalam dua jalur yaitu 1) jalur Rantai Carbon Phosphorus (C-P) menghasilkan fosfat dan sarkosin (C-P) jalur lyase misal Pseudomonas sp. 2) Pembelahan oksidatif 
rantai C-N pada sisi karboksil yang dikatalisasi dengan glifosat oksidoreduktase (GOX), menghasilkan bentuk aminomethylphosphonic acid (AMPA) dan glyoxilate (jalur AMPA). Jalur AMPA tampak lebih dominan pada degradasi glifosat di tanah dengan bakteri gram negatif atau gram positif (Pollegioni et al., 2011). Mekanisme oksidasi memang dapat mempengaruhi toksisitas dari pestisida, misalnya jamur pelapuk putih yang diduga dapat mendegradasi insektisida karbofuran karena mampu menghasilkan enzim ekstraseluler oksidatif (Chanif et al., 2015). Dari jalur AMPA tersebut, dapat dipecah lagi menjadi karbondioksida, air, dan nitrat (Liawati, 2001). Jika dalam jalur AMPA yang dihasilkan adalah karbondioksida sehingga tidak menjadi permasalahan apabila bakteri pemacu pertumbuhan yang membantu degradasi glifosat dan menghasilkan metabolit AMPA.

\begin{tabular}{|c|c|c|}
\hline & $\begin{array}{c}\text { Medium Tanah Tanpa } \\
\text { Enterobacter cloacae }\end{array}$ & $\begin{array}{c}\text { Medium Tanah dengan } \\
\text { Enterobacter cloacae }\end{array}$ \\
\hline Glifosat & 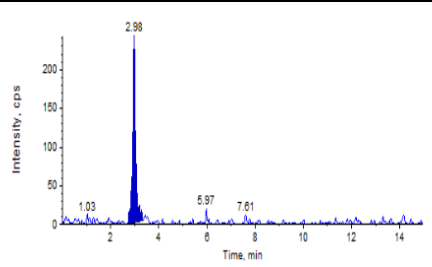 & 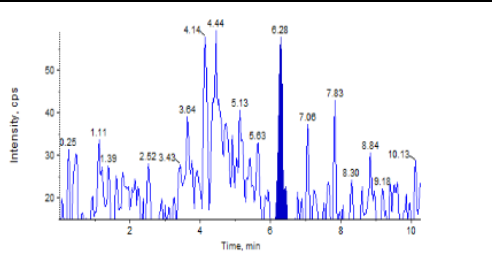 \\
\hline $\begin{array}{l}\text { Aminomethylphospona } \\
\text { te (AMPA) }\end{array}$ & $\left.\right|_{-1} ^{20}$ & | 200. \\
\hline
\end{tabular}

Gambar 3. Hasil kromatogram pengujian residu glifosat

Potensi kemampuan bakteri Enterobacter cloacae dalam mendegradasi glifosat diharapkan membantu penerapan bioremediasi lahan skala luas, seperti yang dijelaskan oleh Bashan et al., (2012) dimana peran bakteri pemacu pertumbuhan endofit dan perakaran (Plant Growth Promoting Bacteria) dalam bioremediasi yaitu pada tahap rhizodegradasi yang dapat meningkatkan aktivitas mikrobial untuk mendegradasi kontaminan misalnya penanaman Festucia arundinacea dengan penambahan bakteri pendegradasi polycyclic aromatic hydrocarbon (PAH) dan Bakteri pemacu pertumbuhan (Plant Growth Promoting Bacteria) yaitu Pseudomonas putida, A. Brasilense dan Enterobacter clocae meningkatkan jumlah degradasi PAH dikarenakan spesies bakteri secara spesifik memitigasi cekaman/ stres pada tanaman dengan adanya mekanisme aktifitas ACC-deaminase. Inokulasi dengan bakteri dalam kondisi medium mengandung herbisida secara signifikan meningkatkan perkecambahan dan munculnya akar. Bakteri yang ditumbuhkan dalam medium mengandung glifosat dapat membantu detoksifikasi glifosat menjadi bahan yang kurang beracun. Bakteri yang digunakan adalah Pseudomonas sp. dan Azospirilium sp. yang toleran terhadap glifosat dan menggunakan glifosat sebagai sumber karbon in vitro (Travaglia et al., 2015).

\section{Kesimpulan \& Saran}

\subsection{Kesimpulan}

Bakteri Enterobacter cloacae memiliki potensi dalam mendegradasi herbisida glifosat. Berdasarkan penelitian, hasil pengujian konsentrasi residu glifosat pada medium tanah yang telah diberikan perlakuan dengan penambahan bakteri Enterobacter cloacae dan Tanpa penambahan bakteri Enterobacter cloacae, yaitu pada perlakuan tanpa penambahan bakteri Enterobacter cloacae, kadar glyfosat yang diperoleh sebanyak 51, 4 ppm dan kadar Aminomethylphosponate (AMPA) sebanyak 4,66 ppm sampel. Sedangkan pada medium tanah dengan penambahan bakteri Enterobacter cloacae, yaitu pada kadar glyfosat sebanyak 0 ppm dan kadar Aminomethylphosponate (AMPA) sebanyak 12,8 ppm sampel. presentase biodegradasi herbisida glifosat dengan menambahkan bakteri Enterobacter cloacae sekitar 100\%.

\subsection{Saran}

Perlu penelitian lebih lanjut mengenai produksi massal bakteri dalam media perbanyakan yang mudah dan murah bagi pengguna (petani). 


\section{Ucapan Terimakasih}

Ucapan terimakasih Kepada Badan Penyuluhan dan Pengembangan SDM Pertanian dan Universitas Brawijaya sebagai pembimbing pakar.

\section{Daftar Referensi}

Bashan, L.E., J.P Hernandes., Y. Bashan. (2012). The Potential Contribution of Plant Growth - Promoting Bacteria to Reduce Environmental Degradation - A Comprehensive Evaluation. Apllied Soil Ecology 61: 171-189.

Chanif, I., Djauhari, S., \& Aini, L. Q. (2015). Uji Potensi Jamur Pelapuk Putih Dalam Bioremediasi Insektisida Karbofuran. Jurnal Hama dan Penyakit Tumbuhan, 3(2), pp-83.

Fauriah, R., Muanisah, U., adan Hidayah, A. (2017). Identifikasi Residu Glifosat pada Lahan Hortikultura di Provinsi Jawa Tengah. Prosiding Seminar Nasional Inovasi Pestisida Ramah Lingkungan Mendukung Swasembada Pangan hal. 121.

Kesuma, S.D., Hariyadi, S. Anwar. (2015). Dampak Aplikasi herbisida IPA Glifosat dalam Sistem Tanpa Olah Tanah (TOT) terhadap Tanah dan Tanaman Padi Sawah. J. Pengelolaan Sumber Daya Alam dan Lingkungan 5 (1): 61-70.

Krishna, K.R., \& Philip, L. (2011). Bioremediation of Single and Mixture of Pesticide-Contaminated Soils by Mixed Pesticide-Enriched Cultures. Applied Biochemistry and Biotechnology, 164(8), 12571277. doi:10.1007/s12010-011-9211-5 .

Liawati, L. (2001). Seleksi Bakteri Tahan Glifosat. Skripsi. Jurusan Biologi Fakultas Matematika dan Ilmu Pengetahuan Alam. Institut Pertanian Bogor.

Lukito, P, K. (2020). Hari Keamanan Pangan di Ritel Pangan pada Era New Normal Available at https://www.pom.go.id/new/view/more/berita/18647/Hari-Keamanan-Pangan-Sedunia---.-Keamanan-Pangan-di-Ritel-Pangan-pada-Era-New-Normal---.html. Accessed at july 1st, 2021.

Moenandir, J. (2010). Ilmu Gulma. UB Press. Malang.

Odukkathil, G. And N. Vasudevan. (2013). Toxicity and Bioremediation of Pesticides in Agricultural Soil. Reviews in Environmental Science and Bio/Technology, 12(4), 421-444.

Pollegioni, L., E. Schonburn., D. Siehl. (2011). Molecular Basis of Glyphosate Resistance: Different Approaches Through Protein Engineering. FeBS J 278(16): 2753-2766.

Stenersen, J. (2004). Mode of Action and Toxicology. CRC Press. USA.

Stepniewska and A. Kuzniar. (2013). Endophytic microorganisms - promising applications in bioremediation of greenhouse gases. J. Appl Microbiol Biotechnol 97:9589-9596.

Travaglia, C., O., Masciarelli, J. Fortuna, G. Marchetti, P. Cardozo, M. Lucero, E. Zorza, V. Luna, and H. Reinoso. 2015. Towards sustainable Maize Production: Glyphosate Detoxification by Azospirillum sp. and Pseudomonas sp. Crop Protection, 77, pp.102-109.

TWN. (2013). RISALAH KEAMANAN HAYATI Biosafety Briefing : Informasi Keamanan Hayati Terkini untuk (jagung) MON810, MON863, NK603 dan (kedelai) GTS-40-3-2.

Zhuang, X., Chen, J., Shim, H., Bai, Z. (2007). New Advances in Plant Growth Promoting Rhizobacteria for Bioremediation. J. Environmental International 33 (2007): 406-413. 